\title{
Tc-99m Labeled HMPAO white Blood Cell Scintigraphy in Pediatric Patients
}

\author{
Pediatrik Hastalarda Tc-99m HMPAO Işaretli Lökosit Sintigrafisi
}

\author{
Funda AydınI, Arzu Kun Cengiz2, Fırat Güngörl \\ IAkdeniz University Medical School, Department of Nuclear Medicine, Antalya, Turkey \\ 2Adnan Menderes University Medical School, Department of Nuclear Medicine, Aydın, Turkey
}

\begin{abstract}
Objective: $99 \mathrm{mTc}$ labeled hexamethylpropylene amine oxime (HMPAO) white blood cell (WBC) scintigraphy is a frequently used option for acute infection, particularly in pediatric patients. This scintigraphy is applied to detect sites of infection/inflammation in patients with fever of unknown origin, to find and follow up osteomyelitis, and to detect suspicion of acute appendicitis. The aim of this retrospective study was to evaluate the value of 99mTc-HMPAO labeled WBC scintigraphy in pediatric patients.

Material and Methods: The study was conducted between January 2006 and December 2008 and included 13 patients (5 boys, 8 girls; mean age 6.9 \pm 6.2 years). Those patients who had suspicion of bone infection $(n=7)$, fever of unknown origin ( $n=3$ ), and suspicion of acute appendicitis $(n=3)$ were evaluated retrospectively. 99mTc-HMPAO labeled WBC scintigraphy imaging was performed to all patients. Diagnosis was done according to operation and pathological results or clinical follow-up.

Results: 99mTc-HMPAO labeled WBC scintigraphy has been found to be true positive in 6 cases, true negative in 6 cases, and false negative in one patient who had fewer unknown origin. The false negative case has been found to have encephalitis with MRI.

Conclusion: Leukocyte scintigraphy has been described as a useful diagnostic tool in the diagnosis of suspicion of bone infection, fever of unknown origin and suspicion of acute appendicitis. 99mTc-HMPAO labeled WBC scintigraphy is a rapid and very accurate method for detecting those pathologies. Our results showed that WBC scintigraphy might be reliably used for diagnosis of suspected bone infection and acute appendicitis, fever of unknown origin, and acute appendicitis, in pediatric patient population.
\end{abstract}

(MIRT 2012,21:13-18)

Key words: 99mTc-HMPAO, scintigraphy, osteomyelitis, fever of unknown origin, appendicitis, pediatrics

\section{Özet}

Amaç: 99mTc hexamethylpropylene amine oxime (HMPAO) ile işaretli lökosit sintigrafisi özellikle çocuklarda akut enfeksiyon için sıklıkla kullanılır. Lökosit sintigrafisi nedeni bilinmeyen ateş olgularında infeksiyon/inflamasyonu tanımlamada, osteomyelit tanısı ve takibinde ve akut apendisit şüphesinde uygulanır. Bu retrospektif çalışmanın amacı pediatrik hastalarda 99mTc HMPAO ile işaretli lökosit sintigrafisini değerlendirmekti.

Gereç ve Yöntemler: Çalışma Ocak 2006 ve Aralık 2008 tarihleri arasında yürütüldü ve 13 hasta (5 erkek, 8 kız; ortalama yaş $6,9 \pm 6,2$ yaş) dahil edildi. Kemik enfeksiyonu şüphesi $(n=7)$, nedeni bilinmeyen ateş $(n=3)$, ve akut apendisit şüphesi ( $n=3)$ olan bu hastalar retrospektif olarak değerlendirildi. 99mTc-HMPAO işaretli lökosit sintigrafisi tüm hastalara yapıldı. Tanı operasyon ve patolojik sonuç veya klinik takibe göre konuldu.

Bulgular: 99mTc-HMPAO işaretli lökosit sintigrafisi 6 olguda gerçek pozitif, 6 vakada gerçek negatif ve nedeni bilinmeyen ateşi olan 1 olguda da yalancı negatif olarak bulundu. Yalancı negatif vakanın tanısı MRI ile konuldu.

Sonuç: Lökosit sintigrafisi kemik enfeksiyonu şüphesinde, nedeni bilinmeyen ateşte ve akut apendisit şüphesinde yararlı tanısal tetkik olarak tanımlanmıştır. 99mTc-HMPAO işaretli lökosit sintigrafisi bu patolojilerin tanısı için hızlı ve çok doğru yöntemdir. Bizim sonuçlarımız pediatrik hasta populasyonunda işaretli lökosit sintigrafisinin enfeksiyon şüphesinde, nedeni bilinmeyen ateşte ve akut apendisit şüphesinde güvenilir olabileceğini gösterdi. (MIRT 2012,21:13-18)

Anahtar kelimeler: 99mTc-HMPAO, sintigrafi, osteomyelit, nedeni bilinmeyen ateş, apendisit, pediatri 


\section{Introduction}

The early and accurate localization of infectious foci is a major challenge in contemporary nuclear medicine. Early and accurate diagnosis and localization allow prompt and successful treatment and decrease associated morbidity (1).

Clinicians have tried to localize, uncover, and monitor sources of infections using various diagnostic schemes including clinical examination and laboratory tests, as well as biologic and anatomic imaging (2).

Nuclear medicine plays an important role in the evaluation of patients (pediatric and adult) suspected of harboring infection. Although Tc-99m MDP, Ga-67 citrate and F-18 FDG all are useful, in vitro labeled leukocyte imaging is the radionuclide gold standard for imaging most infections (3).

Imaging with the use of ex vivo-labeled autologous leukocytes with Indium-111 (111/n) was developed in the 1970 s $(4,5)$. The approach is to use a neutral, lipophilic chelate of $111 \mathrm{ln}$ which is able to enter cells by passive diffusion followed by binding to intracellular macromolecules (6).

The clinical value of early studies with $111 /$ n-labeled leukocytes led to the search for an analogous method using Technetium-99m (99mTc), which is logistically easier to use because of its routine availability from an on-site Molybdenum-99 (99Mo)/ 99mTc generator (6).

Since 1986, 99mTc hexamethylpropylene amine oxime labeled white blood cell (99mTc-HMPAO labeled WBC) scintigraphy has been a frequently used option for acute infection, particularly in pediatric patients $(1,3,7,8,9)$. Conceptually it is similar to the 111 In-oxine approach in that a neutral, lipophilic chelate enters the cells by passive diffusion and is changed into a chemical form which is not able to exit across the cell membrane (6).
The principal clinical indications for using 99mTc-HMPAO labeled WBC scintigraphy are inflammatory bowel disease, acute osteomyelitis and to a lesser extent, occult fever (10). This imaging is also indicated for acute soft tissue infection and to detect suspicion of acute appendicitis (11). WBC scintigraphy is useful in the pediatric group, where $99 \mathrm{mTC}$ methylene diphosphonate (MDP) has low specificity (12).

The aim of this retrospective study was to evaluate the value of 99mTC-HMPAO labeled WBC scintigraphy for the diagnosis of infection and inflammation in pediatric patients.

\section{Material and Methods}

\section{Patient Population}

This study was designed as a retrospective clinical trial. Thirteen patients ( 5 boys and 8 girls; aged between 1-17 years; mean age $6.9 \pm 6.2$ years) were included in this study from January 2006 and December 2008. Patients were referred for 99mTc-HMPAO labeled WBC scintigraphy to evaluate for infection suspected in bone ( $n=7.54 \%)$, fever of unknown origin (FUO) $(n=3.23 \%)$, and suspicion of acute appendicitis ( $n=3.23 \%)$ (Table 1). To discriminate bone infection from soft-tissue infection, we used a combination of labeled leukocyte scintigraphy and $99 \mathrm{mTc}$ MDP three-phase bone scanning.

Before scintigraphy, the children's parents had to sign a written informed consent where all information about the leukocyte labeling and imaging were explained.

\section{Labeling of WBCs}

Leukocytes were labeled in vitro with 99mTc-HMPAO (Ceretec, Amersham Healthcare) using a consensus protocol that was described earlier (13).

Table 1. Summary of the patients

\begin{tabular}{lccccccc}
\hline No & Age & ID & Ethiology & BS & Scintigraphy & Decision & Result \\
\hline 1 & 1 & FUO & & & negative & follow-up & TN \\
2 & 1.5 & FUO & & & negative & follow-up & TN \\
3 & 4 & Ap & & & positive & op & TP \\
4 & 5 & Bone inf & Spontaneous & $(+)$ & positive & op and treat & TP \\
5 & 2.5 & Bone inf & immune deficiency & $(+)$ & positive & treat & TP \\
6 & 16 & Bone inf & Trauma & $(+)$ & negative & follow-up & TN \\
7 & 17 & Bone inf & Trauma & $(+)$ & positive & op and treat & TN \\
8 & 1 & FUO & & & negative & treat & FN* \\
9 & 12 & Bone inf & Trauma & $(+)$ & negative & follow-up & TN \\
10 & 5 & Bone inf & Spontaneous & $(+)$ & positive & treat & TP \\
11 & 17 & Ap & & & negative & follow-up & TN \\
12 & 13 & Ap & & & negative & follow-up & TN \\
13 & 11 & Bone inf & Trauma & $(+)$ & positive & op and treat & TP
\end{tabular}

ID:initial diagnosis; Ap:acute appendicitis; Op:operation; treat:medical treatment; TN:true negative; TP:true positive; FN:false negative; BS: Three-phase bone scintigraphy *Final diagnosis with MRI, encephalitis and brain abcess 


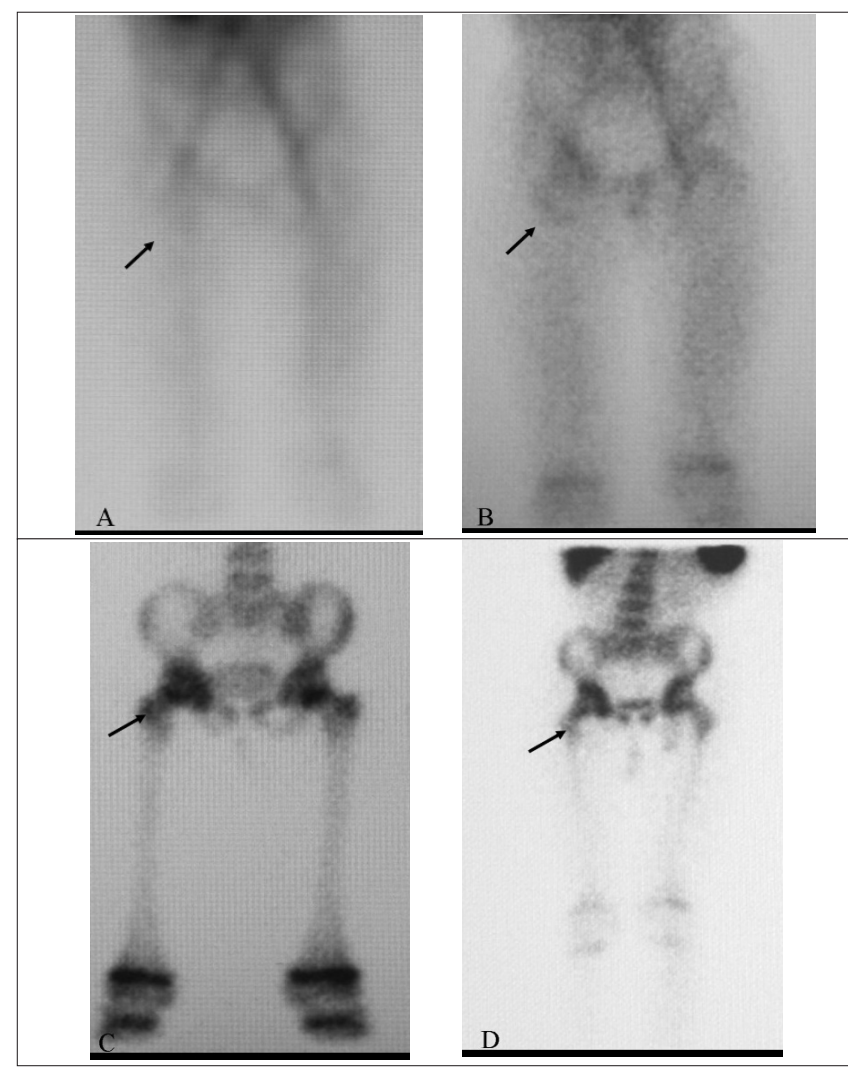

Figure 1. 5 year old female patient with suspected right hip infection. Figure 1A, Figure 1B, Figure 1C. Three-phase bone scintigraphy shows positive uptake in the region of right hip (arrow). Figure 1D. 99mTc-HMPAO labeled WBC scintigraphy shows positive uptake in the same region (arrow) compatible with osteomyelitis. Result: Infected right hip

\section{Imaging Protocol}

Planar whole-body sweep and static imaging were typically performed under a gamma camera (Toshiba GCA 501 S or Sopha DST-XLi) equipped with low-energy all purpose or high resolution collimator starting at the 30th min following the injection of 37-74 MBq 99mTc-HMPAO labeled WBC. Patients were instructed to void before imaging. Imaging was repeated at $1^{\text {th }}, 2^{\text {th }}$, and $4^{\text {th }} \mathrm{h}$. All images were acquired for 10 minutes duration.

\section{Image Interpretation}

The scintigraphic images were reviewed by two nuclear medicine specialists making a comparison between the acquisitions at various times by the following evaluation criteria:

(1) When the scans showed significant change in leukocyte distribution between 1 th hour images compared to the $4^{\text {th }}$ hour images, they were considered positive.

(2) The presence of areas of progressive leukocyte concentration in proportion to time, was also considered as sign of presence of disease.

(3) Scintigraphic examination not matching the above mentioned criteria were considered as negative. Only the scans judged as positive or negative by both specialists were finally accepted as being so. Diagnosis was done according to operation and pathological results, or clinical follow-up.

\section{Analysis of Scintigrams}

99mTc-HMPAO labeled WBC scintigraphy was considered true-positive when an infectious focus identified by scintigraphy was later verified by another method (surgery, biopsy, other imaging modalities, and clinical follow-up). Scintigrams identifying foci that were never verified during follow-up or foci that were verified as noninfectious were considered false-positive. A scintigram was considered truenegative when no infectious process was found during follow-up. Scintigrams were considered false-negative if an infectious focus was identified by other methods.

\section{Results}

Of the 13 patients studied, a final result was obtained in 12 (92\%). 99mTc-HMPAO labeled WBC scintigraphy was found to be true positive in 6 of 13 patients, true negative results were obtained for 6 cases, and false negative in one patient who had FUO. The false negative case has been found encephalitis with MRI (Table1).

Three-phase bone scintigraphy was positive in all children with the suspicion of acute bone infection in our series. 99mTc-HMPAO labeled WBC scintigraphy was found to be true positive in 5 of 7 patients who were evaluated for infection suspected in bone (Figure 1). These cases were treated with antibiotics for more than 6 weeks. Four patients true negative for osteomyelitis did not receive antibiotics.

One of 3 cases who had suspicion of acute appendicitis was operated, and the final diagnosis was acute appendicitis. The other 2 patients had negative scintigraphy for acute appendicitis, and they were not operated on. These patients showed clinical improvement without any treatment.

99mTc-HMPAO labeled WBC scintigraphy was negative in 3 patients who were considered as FUO. Two of them were true negative because no cause was found, and they spontaneously recovered and no fever was observed at the end of follow-up. The remaining 1 patient, has been found to have encephalitis and abscess in left frontal area with MRI (WBC scintigraphy was false negative).

99mTc HMPAO labeled WBC scintigraphy yielded no false positive results.

\section{Discussion}

99mTc-HMPAO labeled WBCs normally accumulate in the liver, spleen, bone marrow, kidneys, and gastrointestinal tract. The principal clinical indications for using $99 \mathrm{mTc}$ HMPAO labeled WBC scintigraphy are inflammatory bowel disease (IBD), acute osteomyelitis and to lesser extent, 
occult fever (10). 99mTC-HMPAO labeled WBC imaging is also indicated for acute soft-tissue and abdominal sepsis (11). In children and where the resolution is bad, such as for small-bowel involvement in Chron's disease, 99mTcHMPAO labeled WBC scintigraphy is preferred because of superior resolution, higher count density and lower radiation dose (14).

Three-phase bone scintigraphy with $99 \mathrm{mTC}-\mathrm{MDP}$ is the study of choice for diagnosing osteomyelitis in bones, and to discriminate bone infection from soft-tissue infection, but this is less specific in patients with fractures or prosthesis $(15,16)$. 99mTc-leukocytes are generally more sensitive for detection of acute osteomyelitis than of chronic osteomyelitis. They are also useful in the pediatric group, where 99mTc-MDP has low specificity (12). It is well known that a diagnosis can be reached without resorting to this diagnostic method in the majority of patients with nonviolated bone tissue. These cases are hematogenous osteomyelitis which can be easily detected by clinical signs and symptoms, laboratory data and three-phase bone scintigraphy (17). Therefore, with a few exceptions, the need for WBCs is restricted to osteomyelitis that has developed in bone already affected by structural changes (previous diseases, orthopedic devices, prostheses etc.) or suspected of having been caused by the spread to the bone of contiguous foci of infection (exposed fractures, osteomyelitis underlying skin ulcers in diabetic foot, etc.) (17). Three-phase bone scintigraphy was positive in all children with the suspicion of bone infection in our series. However, 99mTc- HMPAO labeled WBC scintigraphy was found to be positive in 5 patients and these cases were true-positive, and there were no false-positive or falsenegative results in our group of patients with the suspicion of bone infection.

FUO is an illness of at least 3 weeks duration, with several episodes of fever exceeding $38.3^{\circ} \mathrm{C}$, and no diagnosis after an appropriate inpatient or outpatient evaluation. The underlying causes of FUO are numerous; the most common causes are infections, malignancies and collagen vascular disease $(18,19)$. Identifying the source of an FUO is often difficult; however, radionuclide studies can provide important information. Several investigators have reported that labeled leukocyte imaging is a useful investigation method for this indication $(20,21,22)$. Recently Seshadri et al reported on labeled leukocyte imaging in 54 patients with FUO. Although the sensitivity of the test was only $60 \%$ and the specificity was $73 \%$, the authors found that a negative study in patients with spontaneous FUO virtually excludes infection/ inflammation, and concluded that labeled leukocyte imaging is useful in this population (23).

In this study, 99mTc-HMPAO labeled WBC scintigraphy was negative in 3 patients who were considered to have FUO. Two of them were true negative because no cause was found, and they spontaneously recovered and no fever was observed at the end of the follow-up. The remaining 1 patient has been found to have encephalitis with MRI (WBC scintigraphy was false negative). The application of WBC scintigraphy in brain abscess diagnosis has been reported sporadically and described in greater detail in two published studies $(24,25)$. Rehncrona et al. (24) observed 111 In uptake in four of five brain abscess imaged 24 and 48 h post injection. Bellotti et al. (25) claimed $100 \%$ sensitivity and $94 \%$ specificity of this method for brain abscess detection. However, there are some obvious pitfalls and shortcomings. Cerebral abscess in patients on high-dose steroid treatment may not be detected by WBC scintigraphy (26). Quartey et al. (27) found in rabbit experiments that dexamethasone impedes bacterial killing in brain abscess in animals on antibiotic treatment. This was accompanied by sparse infiltration by granulocytes and compromised granulation tissue and fibrous capsule formation. Neuwelt et al. (28) found high- and medium-dose dexamethasone to suppress macrophage and glial response and to decrease collagen formation. Our false negative case was using dexamethasone and antibiotic treatment.

18F-FDG PET/CT is a useful imaging tool in patients with FUO. When systemic diseases are excluded by other diagnostic tests, a negative PET/CT may avoid the need for further investigation. The synergy of combined anatomicmetabolic information is of incremental value in the diagnostic work-up of FUO. A few studies have found that 18F-FDG PET and PET/CT might be useful to detect the inflammatory focus in $\mathrm{FUO}(29,30)$.

Diagnosing acute appendicitis in children with equivocal signs and symptoms is usually difficult. The usual approach to the patient is hospital observation and frequent reexamination.

However, many surgeons are reluctant to delay surgery because of the risk of perforation and a negative laparatomy (31). The rate of complications, including death, is directly correlated with delay in diagnosis and surgery (32). The fact that no single laboratory test is $100 \%$ accurate for diagnosing appendicitis exacerbates the problem. Plain radiography, barium enema, graded compression ultrasonography and computed tomography have been employed in the attempt to diagnose acute appendicitis with atypical presentations. Since these tests all have limitations and drawbacks, their use has not reduced the number of negative laparotomies or made a significant impact on the clinical management of these patients (33). When all these factors are considered, it is not surprising that attempts to diagnose patients with appendicitis can lead to frustration and confusion for both the patient and the doctor.

There have been a few studies on the use of $99 \mathrm{mTc}$ HMPAO WBC scintigraphy in pediatric cases of suspected appendicitis $(34,35)$. Chang et al. (31) showed that 99mTcHMPAO labeled WBC scintigraphy is a useful and noninvasive test for confirming the clinical diagnosis of 
suspected acute appendicitis in children. In this study, 99mTc-HMPAO labeled WBC scintigraphy had a sensitivity of $96.7 \%$, specificity of $80 \%$ and accuracy of $88 \%$ (31). However, Kanegaye et al. concluded that 99mTc-HMPAO WBC scintigraphy is neither accurate nor reliable as a diagnostic test in pediatric patients with an initial clinical presentation equivocal for appendicitis. Their reported sensitivity and specificity rates for appendicitis using $99 \mathrm{mTC}$ HMPAO labeled WBC scintigraphy are the lowest in the literature (35).

There were 3 cases with suspicion of acute appendicitis in our group of patients. One of 3 cases was operated because the scan was considered positive for acute appendicitis, and final diagnosis was acute appendicitis. The other 2 patients had negative scintigraphy for acute appendicitis, and they were not operated on. These patients showed clinical improvement without any treatment.

The 99mTc-HMPAO WBC scintigraphy as an alternative to the invasive gold standard represented by endoscopy with biopsy is a reliable method both for diagnosis and follow-up in pediatric inflammatory bowel disease (IBD) $(36,37)$. Just a few studies about pediatric patients can be found in the literature, and the results of these studies showed sensitivity between $84 \%$ and $93 \%$, specificity between $81 \%$ and $93 \%$ in the diagnosis of IBD $(38,39)$. The 99mTc-HMPAO labeled WBC scintigraphy has proved itself in correctly defining IBD remission and relapses and in defining lesions location, extension, and severity (37). In children with possible IBD the 99mTc-HMPAO labeled WBC scintigraphy, when compared with endoscopy and biopsy, has a sensitivity rate of $93 \%$, a specificity rate of $97 \%$ (38). These results suggest that $99 \mathrm{mT}$ - - HMPAO labeled WBC scintigraphy is useful as an initial screening method to exclude IBD (38). Therefore, 99mTc-HMPAO labeled WBC scintigraphy is a valid, minimally invasive, and reproducible technique which can give accurate information about the presence or absence of lesions and the intensity and extension of disease in patients affected by IBD in the active state, according to literature data $(36,37,38,39)$.

In summary, leukocyte scintigraphy has been described as a useful diagnostic tool in the diagnosis of suspicion of bone infection, fever of unknown origin and suspicion of acute appendicitis. Tc-99m HMPAO labeled WBC scintigraphy is a rapid and very accurate method for detecting those pathologies.

Our results showed that WBC scintigraphy might be reliably used for diagnosis of suspected bone infection, acute appendicitis, and fever of unknown origin in pediatric patient population.
Furthermore, larger, well-designed, prospective studies are needed to validate and to implement the strategy of using this imaging modality as an initial diagnostic investigation in pediatric patients.

\section{References}

1. Benitez A, Roca M, Martin-Comin J. Labeling of antibiotics for infection diagnosis. Q J Nucl Med Mol Imaging 2006;50:147-152.

2. Djekidel M, Brown RKJ, Piert M. Benefits of hybrid SPECT/CT for $111 \mathrm{ln}$-Oxine- and Tc-99m-Hexamethylpropylene Amine Oximelabeled leukocyte imaging. Clin Nucl Med 2011;36:50-56.

3. Palestro CJ, Love C, Bhargava KK. Labeled leukocyte imaging: current status and future directions. Q J Nucl Med Mol Imaging 2009;53:105-123.

4. Bleeker-Rovers CP, van der Meer JWM, Oyen WJG. Fever of unknown origin. Semin Nucl Med 2009;39:81-87.

5. Segal AW, Arnot RN, Thakur ML, Lavender JP. Indium-111-labeled leucocytes for localisation of abscesses. Lancet 1976;13:1056-1058.

6. Ballinger JR, Gnanasegaran G. Radiolabeled leukocytes for imaging inflammation: how radiochemistry affects clinical use. Q J Nucl Med Mol Imaging 2005;49:308-318.

7. Peters AM, Danpure HJ, Osman S, Hawker RJ, Henderson BL, Hodgson HJ, Kelly JD, Neirinckx RD, Lavender JP. Clinical experience with 99mTc-hexamethylpropyleneamine oxime for labeling leucocytes and imaging inflammation. Lancet 1986;25:946-949.

8. Scholmerich J, Schmidt E, Schumichen C, Billmann P, Schmidt $H_{\text {, }}$ Gerok W. Scintigraphic assessment of bowel involvement and disease activity in Crohn's disease using technetium 99mhexamethyl propylene amine oxime as leukocyte label. Gastroenterology 1988;95:1287-1293.

9. Li DJ, Middleton SJ, Wright EP. 99Tcm and $111 \mathrm{ln}$ leucocyte scintigraphy in inflammatory bowel disease. Nucl Med Commun 1992;13:867-870.

10. Hughes DK. Nuclear medicine and infection detection: the relative effectiveness of imaging with $111 \mathrm{ln}$-oxine-, 99mTcHMPAO-, and 99mTc-stannous fluoride colloid-labeled leukocytes and with 67Ga-citrate. J Nucl Med Technol 2003;31:196-201.

11. McAfee JG. What is the best method for imaging focal infections? J Nucl Med 1990;31:413-416.

12. Peters AM. The utility of [99mTc]HMPAO-leukocytes for imaging infection. Semin Nucl Med 1994;24:110-127.

13. Roca M, Martín-Comín J, Becker W, Bernardo-Filho M, Gutfilen B, Moisan A, Peters M, Prats E, Rodrigues M, Sampson C, Signore $A$, Sinzinger $H$, Thakur M. A consensus protocol for white blood cells labeling with technetium-99m hexamethylpropylene amine oxime. Eur J Nucl Med 1998;25:797-799.

14. Chianelli M, Mather SJ, Martin-Comin J, Signore A. Radiopharmaceuticals for the study of inflammatory processes: a review. Nucl Med Commun 1997;18:437-455.

15. Palestro CJ, Torres MA. Radionuclide imaging in orthopedic infections. Semin Nucl Med 1997;27:334-345.

16. Love C, Palestro CJ. Radionuclide imaging of infection. J Nucl Med Technol 2004;32:47-57.

17. Elgazzar AH, Abdel-Dayem HM, Clark JD, Maxon HR 3rd. Multimodality imaging of osteomyelitis. Eur J Nucl Med 1995;22:1043-1063.

18. Palestro CJ, Torres MA. Radionuclide imaging of nonosseous infections. Q J Nucl Med 1999;43:46-60.

19. Roth AR, Basello GM. Approach to the adult patient with fever of unknown origin. Am Fam Physician 2003;68:2223-2228.

20. Syrjala MT, Valtonen $V$, Liewendahl K, Myllyla G. Diagnostic significance of indium-111 granulocyte scintigraphy in febrile patients. J Nucl Med 1987;28:155-160. 
21. Schmidt KG, Rasmussen JW, Sørensen PG, Wedebye IM. Indium111-granulocyte scintigraphy in the evaluation of patients with fever of undetermined origin. Scand J Infect Dis 1987;19:339-345.

22. Kelly MI, Kalff V, Hicks RJ, Spicer WJ, Spelman OW. 111In-oxine labeled leukocyte scintigraphy in the detection and localization of active inflammation and sepsis. Med J Aust 1990;152:352-357.

23. Seshadri N, Solanki CK, Balan K. Utility of 111 In-labeled leukocyte scintigraphy in patients with fever of unknown origin in an era of changing disease spectrum and investigational techniques. Nucl Med Commun 2008;29:277-282.

24. Rehncrona S, Brismar J, Holtås S. Diagnosis of brain abscesses with indium-111-labeled leukocytes. Neurosurgery 1985;16:23-26.

25. Bellotti C, Aragno MG, Medina M, Viglietti AL, Oliveri G, Ettorre F, Barrale S, Camuzzini G. Differential diagnosis of Cr-hypodense cranial lesions with indium-111-oxine labeled leukocytes. J Neurosurg 1986;64:750-753.

26. Schmidt KG, Rasmussen JW, Frederiksen PB, Kock-Jensen $C$ Pedersen NT. Indium- 111-granulocyte scintigraphy in brain abscess diagnosis: limitations and pitfalls. J Nucl Med 1990;31:1121-1127.

27. Quartey GRC, Johnston JA, Rozdilsky B. Decadronin the treatment of cerebral abscess. J Neurosurg 1976; 45:301-310

28. Neuwelt EA, Lawrence MS, Blank NK. Effect of gentamicin and dexamethasoneon the natural historyof the rat Escherichia coli brain abscess model with histopathological correlation. Neurosurgery 1984;15:475-483.

29. Jasper N, Däbritz J, Frosch M, Loeffler M, Weckesser M, Foell D. Diagnostic value of [18F]-FDG PET/CT in children with fever of unknown origin or unexplained signs of inflammation. Eur J Nucl Med Mol Imaging 2010;37:136-145.

30. Love C, Tomas MB, Tronco GG, Palestro CJ. FDG PET of infection and inflammation. Radiographics 2005;25:1357-1368.

31. Chang CC, Tsai CY, Lin CC, Jeng LB, Lee CC, $\mathrm{Kao} C H$. Comparison between technetium-99m examethylpropyleneamineoxide labeled white blood cell abdomen scan and abdominal sonography to detect appendicitis in children with an atypical clinical presentation. Hepatogastroenterology 2003;50:426-429.
32. Colak T, Güngör F, Ozuğur S, Bozan H, Yildiz A, Boz A, Karayalçin B, Akaydin M, Melikoğlu M. The value of 99mTc-HMPAO labeled white blood cell scintigraphy in acute appendicitis patients with an equivocal clinical presentation. Eur J Nucl Med 2001;28:575-580.

33. Sarfati MR, Hunter GC, Witzke DB, Bebb GG, Smythe SH, Boyan S, Rappaport WD. Impact of adjunctive testing on the diagnosis and clinical course of patients with acute appendicitis. Am J Surg 1993;166:660-665.

34. Yan DC, Shiau YC, Wang JJ, Ho ST, Kao CH. Improving the diagnosis of acute appendicitis in children with atypical clinical findings using the technetium-99m hexamethylpropylene amine oxime-labelled white-blood-cell abdomen scan. Pediatr Radiol 2002;32:663-666.

35. Kanegaye JT, Vance CW, Parisi M, Miller JH, Mahour GH, Chan LS, Schonfeld N. Failure of technetium-99m hexamethylpropylene amine oxime leukocyte scintigraphy in the evaluation of children with suspected appendicitis. Pediatr Emerg Care 1995;11:285-290.

36. Caobelli $F$, Panarotto MB, Andreoli $F$, Ravelli $A$, De Agostini $A$, Giubbini R. Is $99 \mathrm{mTc}-\mathrm{HMPAO}$ granulocyte scan an alternative to endoscopy in pediatric chronic inflammatory bowel disease (IBD)? Eur J Pediatr 2011;170:51-57.

37. Aydın F, Dinçer D, Güngör F, Boz A, Akça S, Yıldız A, Tosun O, Karayalçın B. Technetium-99m hexamethyl propylene amine oxime-labeled leukocyte scintigraphy at three different times in active ulcerative colitis: comparison with colonoscopy and clinicobiochemical parameters in the assessment of disease extension and severity. Ann Nucl Med 2008;22:371-377.

38. Giaffer $\mathbf{M H}$, Tindale $\mathrm{WB}$, Holdsworth D. Value of technetium99m-HMPAO-labeled leukocytes scintigraphy as an initial screening test in patients suspected of having inflammatory bowel disease. Eur J Gastroenterol Hepatol 1996;8:1195-1200.

39. Grahnquist L, Chapman SC, Hvidsten S, Murphy MS. Evaluation of $99 \mathrm{mTc}-\mathrm{HMPAO}$ leukocyte scintigraphy in the investigation of pediatric inflammatory bowel disease. J Pediatr 2003;143:48-53. 